\title{
EVALUASI PENERAPAN PROSEDUR OPERASIONAL STANDAR PENGELOLAAN KEUANGAN DAERAH DI PROVINSI PAPUA
}

\author{
Yemima Eka Christy \\ Fakultas Ekonomika dan Bisnis, Universitas Kristen Satya Wacana \\ Elisabeth Penti Kurniawati \\ Fakultas Ekonomika dan Bisnis, Universitas Kristen Satya Wacana \\ bet@staff.uksw.edu
}

\begin{abstract}
Implementation of Standard Operating Procedures (SOP) in the regional financial management should be conducted based on an internal control system in the local government. When conducting the examination, BPK shall examine and assess the internal control system of the local government. Thus, if the internal control system of the local government is adequate, then compliance toward SOP can be implemented, and the results of the testing and examination of BPK is expected to give a favorable opinion. The provincial government of Papua has decreased the results of the examination of financial statements for three consecutive years. In 2007-2009 the provincial government of Papua gets a qualified opinion, and in 2010 received a disclaimer opinion. The purpose of this study was to evaluate SOP application compliance of regional financial management, which can be known to through BPK examination report containing the findings and their opinions based on the criteria. The results showed that theProvincial Government of Papua has prepared SOP of its financial management in line with the rule in force. However, the SOP is not fully adhered to in practice, due to several factors: (1) weak of government internal control systems;(2) lack of financial management guidance and supervision.
\end{abstract}

Keywords: Standard Operating Procedures, Regional Financial Management

\section{PENDAHULUAN}

Kinerja dan pengelolaan atas keuangan daerah saat ini menduduki posisi penting dalam strategi pemberdayaan pemerintah daerah terlebih lagi dalam proses perwujudan pelaksanaan otonomi daerah dan mewujudkan desentralisasi yang luas, nyata dan bertanggung jawab dalam upaya mewujudkan tujuan pemerintahan daerah yang bersih (clean government). Maksud dari pengelolaan keuangan daerah yang 
baik adalah kemampuan pemerintah dalam mengontrol kebijakan keuangan daerah secara ekonomis, efisien, transparan dan akuntabel.

Salah satu aspek dari pemerintahan daerah yang harus diatur secara hati-hati adalah masalah pengelolaan keuangan daerah dan anggaran daerah. Hal ini menduduki posisi sentraldalam upaya penyelenggaraan urusan pemerintahan yang menjadi kewenangan daerah seperti pengembangan kapabilitas dan efektivitas pemerintah daerah yang didanai dari dan atas beban anggaran pendapatan dan belanja daerah, yang merupakan dasar pengelolaan keuangan daerah dalam masa satu tahun anggaran (Mardiasmo, 1999:11). Pemerintah telah mengatur pengelolaan keuangan daerah dalam Permendagri No.13 tahun 2006 tentang Pedoman Pengelolaan Keuangan Daerah dan Permendagri No.59 tahun 2007 atas perubahan Permendagri No.13 tahun 2006. Dalam implementasi Pedoman Pengelolaan Keuangan Daerah, pemerintah daerah harus mempersiapkan diri untuk melakukan pengelolaan keuangan daerah yang meliputi perencanaan, pelaksanaan, penatausahaan, pelaporan, pertanggungjawaban dan pengawasan keuangan.

Di samping kebijakan akuntansi, pemerintah daerah juga harus memiliki Sumber Daya Manusia (SDM) yang mampu menyusun laporan keuangan daerah yang sesuai dengan Permendagri No.59 tahun 2007 dan Peraturan Pemerintah No.24 tahun 2005 tentang Standar Akuntansi Pemerintahan. Hal ini merupakan salah satu tuntutan yang harus dipenuhi dari Permendagri No.59 tahun 2007 yaitu setiap SKPD harus menyusun laporan keuangannya masing-masing. Laporan keuangan disusun dan disajikan sesuai dengan Standar Akuntansi Pemerintahan (SAP).

Pemerintah daerah Provinsi Papua menjalankan otonomi daerah sebagai implementasi UU No.32 tahun 2004 tentang Pemerintah Daerah dan UU No.21 tahun 2001 tentang otonomi khusus (otsus) bagi Provinsi Papua. Dalam rangka pelaksanaan pembangunan maka dituntut suatu proses perencanaan program dan anggaran yang baik serta didukung oleh kualitas kinerja aparat pemerintah daerah Provinsi Papua dalam hal pengelolaan keuangan daerah sebagai konsekuensi dari ketersediaan dana yang memadai, sehingga diharapkan terciptanya kualitas pelayanan kepada masyarakat.

Dalam pengelolaan keuangan daerah, pemerintah Provinsi Papua memiliki dan menerapkan prosedur kerja yang standar (Prosedur Operasional Standar/POS) sesuai ketetapan PP No.58 Tahun 2005 pasal 151 ayat 2 dimana berdasarkan peraturan daerah mengenai ketentuan pokok pengelolaan keuangan daerah, kepala daerah menetapkan aturan tentang sistem dan prosedur pengelolaan keuangan daerah. POS adalah pedoman atau acuan untuk melaksanakan tugas pekerjaan sesuai dengan fungsi dan alat penilaian kinerja instansi pemerintah berdasarkan indikatorindikator teknis, administratif dan prosedural sesuai dengan tata kerja, prosedur kerja dan sistem kerja pada unit kerja yang bersangkutan, sehingga dapat terukur dan dapat dievaluasi keberhasilannya. Tujuan POS adalah menciptakan komitmen dan kesesuaian mengenai apa yang dikerjakan oleh satuan unit kerja instansi pemerintahan agar capaian kinerja (target) tercapai sesuai perencanaan untuk 
mewujudkan good governance.POS pengelolaan keuangan daerah disusun berdasarkan ketentuan pokok-pokok pengelolaan keuangan daerah yang diatur dengan peraturan daerah sesuai dengan ketentuan peraturan perundang-undangan (PP No.58 Tahun 2005 pasal 151 ayat (1)).

Dalam pelaksanaan prosedur operasional standar pengelolaan keuangan daerah harus diselenggarakan berdasarkan Sistem Pengendalian Intern (SPI) di lingkungan pemerintah daerah (Pemda) yang bersangkutan seperti yang diamanatkan dalam pasal 56 ayat (4) UU No.01 Tahun 2004 yang menyatakan pemerintah daerah memberi pernyataan bahwa pengelolaan keuangan daerah pada daerahnya telah diselenggarakan berdasarkan SPI yang memadai.Dalam melaksanakan pemeriksaan guna meningkatkan kualitas transparansi dan akuntabilitas, BPK wajib menguji dan menilai SPI pemda yang bersangkutan sesuai dengan yang diamanatkan dalam (UU No.15 tahun 2004). Apabila sistem pengendalian intern dijalankan secara memadai oleh pemda yang bersangkutan, maka kepatuhan terhadap POS pengelolaan keuangan daerah dapat terlaksana dan hasil pengujian serta pemeriksaan BPK dapat memberikan opini yang baik.

Berdasarkan laporan hasil pemeriksaan atas laporan keuangan pemerintah Provinsi Papua oleh BPK-RI selama tiga tahun (2007-2009) secara berturut-turut Provinsi Papua mendapat opini wajar dengan pengecualian (WDP), namun pada TA 2010 mengalami penurunan opini dimana BPK-RI tidak dapat memberikan pendapat (disclaimer) atas laporan keuangan Provinsi Papua.

Berpijak dari hal tersebut, penelitian ini mengevaluasi penerapan prosedur operasional standar pengelolaan keuangan daerah di Provinsi Papua. Penelitian ini bertujuan dapat memberikan hasil evaluasi tertulis atas identifikasi kepatuhan penerapan POS pengelolaan keuangan daerah yang dapat diketahui diantaranya melalui laporan hasil pemeriksaan BPK yang memuat opini beserta temuan-temuan berdasarkan kriteria kesesuaian dengan Standar Akuntansi Pemerintah, kecukupan pengungkapan, kepatuhan terhadap peraturan perundang-undangan yang berlaku, serta keefektifan Sistem Pengendalian Intern, sehingga BPKAD bisa mengkoreksi apabila terdapat ketidakpatuhan dalam pelaksanaan POS pengelolaan keuangan daerah yang pada akhirnya dapat membantu memperlancar tugas dari masingmasing unit kerja, menghindari adanya penyimpangan dan mempermudah dalam evaluasi terhadap masalah-masalah yang terjadi.

\section{TELAAH TEORITIS}

\section{Prosedur Operasional Standar (POS)}

Prosedur Operasional Standar atau POS, dalam bahasa Inggris diterjemahkan menjadi Standard Operating Procedures (SOP) yaitu prosedur operasi yang baku. Istilah lain yang sering digunakan dalam bahasa Indonesia adalah PROTAP atau Prosedur Tetap. POS adalah dokumen tertulis yang memuat prosedur kerja secara rinci, tahap demi tahap dan sistematis. Untuk melengkapi suatu prosedur kerja, POS 
sering dilengkapi dengan referensi, lampiran, diagram atau alur kerja (flowchart)(Rahman2003).

Tambunan (2008:79-80) menyebutkan kriteria POS yang baik yaitu efektif, efisien, konsisten, standar dan sistematis. POS yang efektif dapat menghasilkan sejumlah pekerjaan tepat pada waktunya.Menunjukkankeberhasilan dari segi tercapai tidaknya sasaran yang telah ditetapkan. POS yang efisien akan menghasilkan hasil yangoptimal dengan tidak membuang banyak waktu dalam proses pengerjaannya atas sesuatu yang kita kerjakan. POS harus sesuai dengan aturan-aturan yang berlaku, taat asas dan tidak berubah-ubah. POS harus taat pada ketentuan-ketentuan yang menunjukkan persyaratan dan secara umum tidak bertentangan dengan standar atau kode lain, atau bila diadopsi menjadi ketentuan hukum tidak bertentangan dengan ketentuan hukum yang berlaku. Dalam penyusunannya POS disusun tahap demi tahap dan tersistem dengan baik serta terperinci.

Unsur-unsur POS adalah tujuan, kebijakan, petunjuk operasional, pihak terlibat, formulir, masukan, proses, laporan, validasi dan kontrol(Tambunan 2008:120-143). Tujuan memuat hal yang dicapai untuk penyusunan POS. Kebijakan, sebagai pedoman dan rujukan yang harus ditaati dalam pengambilan keputusan dan pelaksanaan kegiatan. Petunjuk operasional, untuk mengarahkan pengguna dalam memahami berbagai bentuk tampilan dan simbol-simbol yang digunakan dalam prosedur yang bersangkutan. Pihak terlibat, pihak atau unit dan fungsi-fungsi yang terlibat dalam prosedur yang bersangkutan. Formulir, bentuk standar dari dokumendokumen kosong atau lazim atau disebut juga blanko atau dokumen yang digunakan dalam menjalankan prosedur tertentu dalam POS sebagai media yang menghubungkan keputusan dan pelaksanaan kegiatan di antara pihak-pihak terlibat. Masukan, seperti pengisian formulir, blanko atau dokumen. Proses, data dan informasi yang terdapat di dalam masukan diubah menjadi informasi yang dibutuhkan organisasi untuk mengambil keputusan dan melaksanakan berbagai kegiatan untuk mencapai tujuan dan target-target yang ditetapkan, baik untuk jangka pendek maupun jangka panjang. Laporan, hasil pengolahan yang memiliki makna tertentu dan dapat dimanfaatkan sebagai sumber pengambilan keputusan di dalam organisasi. Validasi, untuk memastikan bahwa semua keputusan yang diambil dan kegiatan yang dilakukan telah absah atau valid. Kontrol, tindakan yang dilakukan untuk menjaga agar setiap keputusan dan tindakan dalam organisasi berjalan sesuai standar dan aturan yang sudah ditetapkan.

Menurut Tambunan (2008:96-104), manfaat POS adalah: (1) menjadi pedoman kebijakan yang menjadi dasar dari semua kegiatan-kegiatan organisasi, operasional dan administratif. Dengan adanya POS, diharapkan kebijakan-kebijakan organisasi menjadi lebih layak terap dan mencapai manfaat yang optimal, (2) menjadi pedoman pelaksanaan kegiatan organisasi, baik operasional maupun administratif. Dengan adanya POS, organisasi diharapkan mampu berperan mengurangi pengulangan kerja yang tidak perlu, (3) menjadi pedoman validasi langkah-langkah kegiatan dalam organisasi. POS diharapkan organisasi mampu 
membuat birokrasi kegiatannya menjadi lebih jelas dan tidak berbelit-belit, (4) menjadi pedoman penggunaan formulir, blanko dan laporan-laporan yang terkait dengan kegiatan-kegiatan dalam organisasi. Dengan POS diharapkan organisasi mampu mengadministrasikan kegiatannya secara baik, (5) menjadi pedoman penilaian efektifitas kegiatan organisasi. Dengan adanya POS, diharapkan organisasi memiliki ukuran-ukuran kinerja yang lebih baik, (6) menjadi pedoman pengintegrasian kegiatan-kegiatan dalam organisasi, yaitu dalam konteks mencapai tujuan organisasi. Dengan adanya POS, organisasi diharapkan memiliki rangkaian alur-alur kerja yang terpadu satu sama lain.

\section{Pengelolaan Keuangan Daerah}

Pengelolaan keuangan daerah adalah keseluruhan kegiatan yang meliputi perencanaan pelaksanaan, penatausahaan, pelaporan, pertanggungjawaban dan pengawasan keuangan daerah (PP 58/2005, pasal 1). Menurut Jaya (1999:11), keuangan daerah adalah seluruh tatanan, perangkat kelembagaan dan kebijaksanaan anggaran daerah yang meliputi pendapatan dan belanja daerah. Mamesah (1995:16) berpendapat keuangan daerah merupakan semua hak dan kewajiban yang dapat dinilai dengan uang, demikian pula segala sesuatu baik berupa uang maupun barang yang dapat dijadikan kekayaan daerah sepanjang belum dimiliki atau dikuasai oleh negara atau daerah yang lebih tinggi, serta pihak lain sesuai dengan ketentuan peraturan yang berlaku.

Mardiasmo (2000:3) mengemukakan bahwa dalam pemberdayaan pemerintah daerah, maka perspektif perubahan yang diinginkan dalam pengelolaan keuangan daerah dan anggaran daerah ialah: (1) pengelolaan keuangan daerah harus bertumpu pada kepentingan publik (public oriented); (2) kejelasan tentang misi pengelolaan keuangan daerah pada umumnya dan anggaran pada khususnya; (3) desentralisasi pengelolaan keuangan dan kejelasan peran partisipasi yang terkait dalam pengelolaan anggaran, DPRD, Sekda dan perangkat daerah lainnya; (4) kerangka hukum dan administrasi atas pembiayaan, investasi dan pengelolaan keuangan daerah berdasarkan kaidah mekanisme pasar, value for money, transparansi dan akuntabilitas; (5) kejelasan tentang kedudukan keuangan DPRD dan PNS daerah, baik rasio maupun dasar perimbangannya; (6) ketentuan bentuk dan struktur anggaran, anggaran kerja dan anggaran multi tahunan; (7) prinsip pengadaan dan pengelolaan barang daerah yang lebih profesional; (8) prinsip akuntansi pemerintah daerah, laporan keuangan, peran DPRD, peran akuntan publik dan pengawasan, pemberian opini dan rating kinerja anggaran dan transparansi informasi anggaran kepada publik; (9) aspek pembinaan dan pengawasan yang meliputi batasan pembinaan, peran asosiasi dan peran anggota masyarakat guna pengembangan profesionalisme aparat pemerintah daerah; (10) pengembangan sistem informasi keuangan daerah untuk menyediakan informasi anggaran yang akurat dan pengembangan komitmen pemerintah daerah terhadap penyebarluasan informasi. 
Darise (2008:18) menjelaskan bahwa kepala daerah selaku pemegang kekuasaan pengelolaan keuangan daerah melimpahkan sebagian atau seluruh kekuasaannya berupa perencanaan, pelaksanaan, penatausahaan, pelaporan dan pertanggungjawaban serta pengawasan keuangan daerah kepada: Sekretaris Daerah selaku koordinator pengelolaan keuangan daerah, Kepala Satuan Kerja Pengelola Keuangan Daerah selaku PPKD (Pejabat Pengelola Keuangan Daerah) dan Kepala Satuan Kerja Pemerintah Daerah (SKPD) selaku pengguna anggaran/barang daerah.

Penetapan para pengelola keuangan daerah merupakan salah satu syarat pelaksanaan anggaran. Pelimpahan sebagian atau seluruh kekuasaan didasarkan pada prinsip pemisahan kewenangan antara yang memerintahkan, menguji dan yang menerima atau mengeluarkan uang.

Keuangan daerah harus dikelola dengan baik agar semua hak dan kewajiban daerah yang dapat dinilai dengan uang dapat dimanfaatkan semaksimal mungkin untuk kepentingan daerah. Berdasarkan UU 33 tahun 2004 pasal 66 ayat 1, keuangan daerah harus dikelola secara tertib, taat pada peraturan perundang-undangan, efisien, ekonomis, efektif, transparan dan bertanggungjawab dengan memperhatikan keadilan, kepatuhan dan manfaat untuk masyarakat.

Laporan keuangan pemerintah daerah adalah laporan keuangan konsolidasi yang disusun berdasarkan laporan keuangan Satuan Kerja Perangkat Daerah serta laporan pertanggungjawaban pengelolaan perbendaharaan daerah. Laporan keuangan konsolidasi adalah suatu laporan keuangan yang merupakan gabungan keseluruhan laporan keuangan entitas pelaporan sehingga tersaji sebagai satu entitas tunggal (Kebijakan Akuntansi Pemprov Papua).

\section{METODA PENELITIAN}

Penelitian ini menggunakan metoda deskriptif kualitatif,dengan dua jenis data yaitu, data primer dan data sekunder. Data primer berupa hasil wawancara mengenai POS pengelolaan keuangan daerah yang berlaku dan diterapkan di Provinsi Papua dengan kepala dan staf BPKAD Provinsi Papua. Data sekunder berupa dokumentasi POS pengelolaan keuangan daerah yakni dokumen penerimaan dan pengeluaran daerah. Satuan pengamatan adalah bendahara dan unit-unit kerja dalam instansi BPKAD, serta satuan analisis yang digunakan dalam penelitian ini adalah instansi BPKAD di Provinsi Papua yang berada di Jayapura.

Adapun langkah-langkah menganalisis dalam penelitian ini: pertama, menggambarkan dan mengidentifikasikan POS pengelolaan keuangan daerah Provinsi Papua; kedua, mengevaluasi kesesuaian POS pengelolaan keuangan daerah Provinsi Papua terhadap Permendagri No. 13 Tahun 2006; ketiga, mengevaluasi kepatuhan penerapan POS pengelolaan keuangan daerah Provinsi Papua; keempat, menentukan hambatan-hambatan yang memengaruhi ketidakpatuhan pelaksanaan POS pengelolaan keuangan daerah Provinsi Papua; kelima, memberikan kesimpulan 
dan saran pada pengelola atau pihak manajemen BPKAD atas hasil analisis terhadap POS pengelolaan keuangan daerah Provinsi Papua.

\section{ANALISIS DATA}

\section{Gambaran Umum Objek Penelitian}

Objek penelitian ini adalah Badan Pengelolaan Keuangan dan Aset Daerah Provinsi Papua (BPKAD).BPKAD adalah unsur penunjang pemerintahan daerah dalam pengelolaan keuangan dan kekayaan daerah. BPKAD mempunyai tugas melaksanakan sebagian kewenangan pemerintah daerah bidang pengelolaan keuangan dan kekayaan daerah.

Saat ini Pemerintah Provinsi Papua dalam melakukan Pengelolaan Keuangan Daerah sesuai dengan prinsip otonomi daerah, dimana kekuasaan yang berhubungan dengan pengelolaan keuangan daerah diserahkan oleh Presiden diserahkan kepada kepala pemerintah daerah. Untuk itu Pemerintah Provinsi Papua memiliki POSsendiri yang disusun dengan mengacu kepada Permendagri No.13 Tahun 2006 dan Permendagri No.59 tahun 2007 atas perubahan Permendagri No.13 tahun 2006 yang merupakan ketentuan lanjutan dari PP No.58 tahun 2005.

\section{Prosedur Operasional Standar Pengelolaan Keuangan Daerah Provinsi Papua Pelaksanaan dan Penatausahaan APBD Prosedur Penyusunan APBD}

Pejabat Pengelola Keuangan Daerah (PPKD) membuat dan menyerahkan surat pemberitahuan kepada SKPD untuk menyusun rancangan Dokumen Pelaksanaan Anggaran (DPA-SKPD). Berdasar pada Peraturan Daerah tentang Anggaran Pendapatan dan Belanja Daerah (APBD) dan Peraturan Gubernur tentang penjabaran APBD paling lambat tiga hari setelah APBD ditetapkan. SKPD menyerahkan rancangan DPA-SKPD dan rancangan anggaran kas SKPD yang disusunnya kepada PPKD (Kepala SKPD).Rancangan DPA-SKPD merinci sasaran yang hendak dicapai, fungsi, kegiatan dan anggaran yang disediakan untuk mencapai sasaran tersebut, serta rencana penarikan dana tiap-tiap SKPD serta pendapatan yang diperkirakan. Berdasarkan rancangan DPA-SKPD, disusun rancangan anggaran kas SKPD. Keduanya disusun paling lambat enam hari kerja setelah pemberitahuan PPKD.

Verifikasi rancangan DPA-SKPD dan rancangan anggaran kas SKPD bersama-sama SKPD oleh Tim Anggaran Pemerintah Daerah (TAPD) didasarkan pada peraturan Gubernur tentang Penjabaran APBD, yang harus diselesaikan paling lambat 15 hari kerja sejak ditetapkannya peraturan gubernur tentang penjabaran APBD. Rancangan DPA-SKPD yang lolos verifikasi oleh TAPD diserahkan kepada Sekretaris daerah untuk mendapat persetujuan dan Rancangan Anggaran Kas SKPD. Rancangan yang lolos verifikasi diserahkan kepada PPKD untuk selanjutnya disusun oleh PPKD selaku Bendahara Umum Daerah (BUD) menjadi Anggaran Kas Pemerintah Daerah. Dokumen ini akan digunakan sebagai dokumen penyediaan 
dana. Dengan persetujuan Sekretaris Daerah, PPKD mengesahkan Rancangan DPASKPD menjadi DPA-SKPD.

Saat ini Pemerintah Provinsi Papua dalam melakukan Pengelolaan Keuangan Daerah sesuai dengan prinsip otonomi daerah, dimana kekuasaan yang berhubungan dengan pengelolaan keuangan daerah diserahkan oleh Presiden diserahkan kepada kepala pemerintah daerah. Untuk itu Pemerintah Provinsi Papua memiliki POSsendiri yang disusun dengan mengacu kepada Permendagri No.13 Tahun 2006 dan Permendagri No.59 tahun 2007 atas perubahan Permendagri No.13 tahun 2006 yang merupakan ketentuan lanjutan dari PP No.58 tahun 2005.

\section{Prosedur Pelaksanaan dan Penatausahaan Penerimaan Daerah}

Penyelenggaraan urusan pemerintahan yang menjadi kewenangan daerah didanai dari dan atas beban APBD. Dalam APBD dianggarkan pendapatan daerah sebagai sumber dana guna membiayai belanja daerah. Penerimaan dan pengeluaran yang dianggarkan dalam APBD dilakukan melalui rekening kas umum daerah yang dikelola oleh bendahara umum daerah. Semua penerimaan daerah apabila berbentuk uang harus segera disetor ke Kas Umum Daerah dan apabila berbentuk barang akan dicatat sebagai inventarisasi daerah. Setiap penerimaan harus didukung oleh bukti yang lengkap atas setiap transaksi penerimaan sesuai dengan keadaan yang sebenarnya.

Pengguna anggaran menyerahkan surat ketetapan pajak daerah (SKP)/surat ketetapan retribusi (SKR) kepada Bendahara Penerimaan dan Wajib Pajak (WP)/ Wajib Retribusi (WR). WP/WR membayarkan sejumlah uang sesuai yang tertera di SKP/SKR pada Kas Daerah dengan mengisi slip setoran atau bukti lain yang sah yang dibuat rangkap tiga. Berdasarkan slip setoran atau bukti lain yang sah tersebut Bidang Kas Daerah mengotorisasi dan mencatat sebagai pendapatan. Bidang Kas Daerah menyerahkan rangkap satu dan dua kepada WP/WR yang selanjutnya rangkap dua diserahkan kepada Bendahara Penerimaan sebagai bahan untuk melakukan penatausahaan.

Penatausahaan penerimaan daerah disusun berdasarkan dokumen SKP daerah, SKR, STS (Surat Tanda Setoran) dan STBP (Surat Tanda Bukti Pembayaran) atau bukti lain yang sah. Dalam penerimaan daerah Bendahara Penerimaan wajib menyelenggarakan penatausahaan terhadap seluruh penerimaan dan penyetoran yang menjadi tanggungjawabnya. Dalam pelaksanaan dan penatausahaan bendahara penerimaan dilarang menyimpan uang, cek atau surat berharga yang dalam penguasaannya lebih dari satu hari kerja dan/atau, menyimpan dan membuka rekening atas nama pribadi pada bank atau giro pos atas pelaksanaan APBD. 


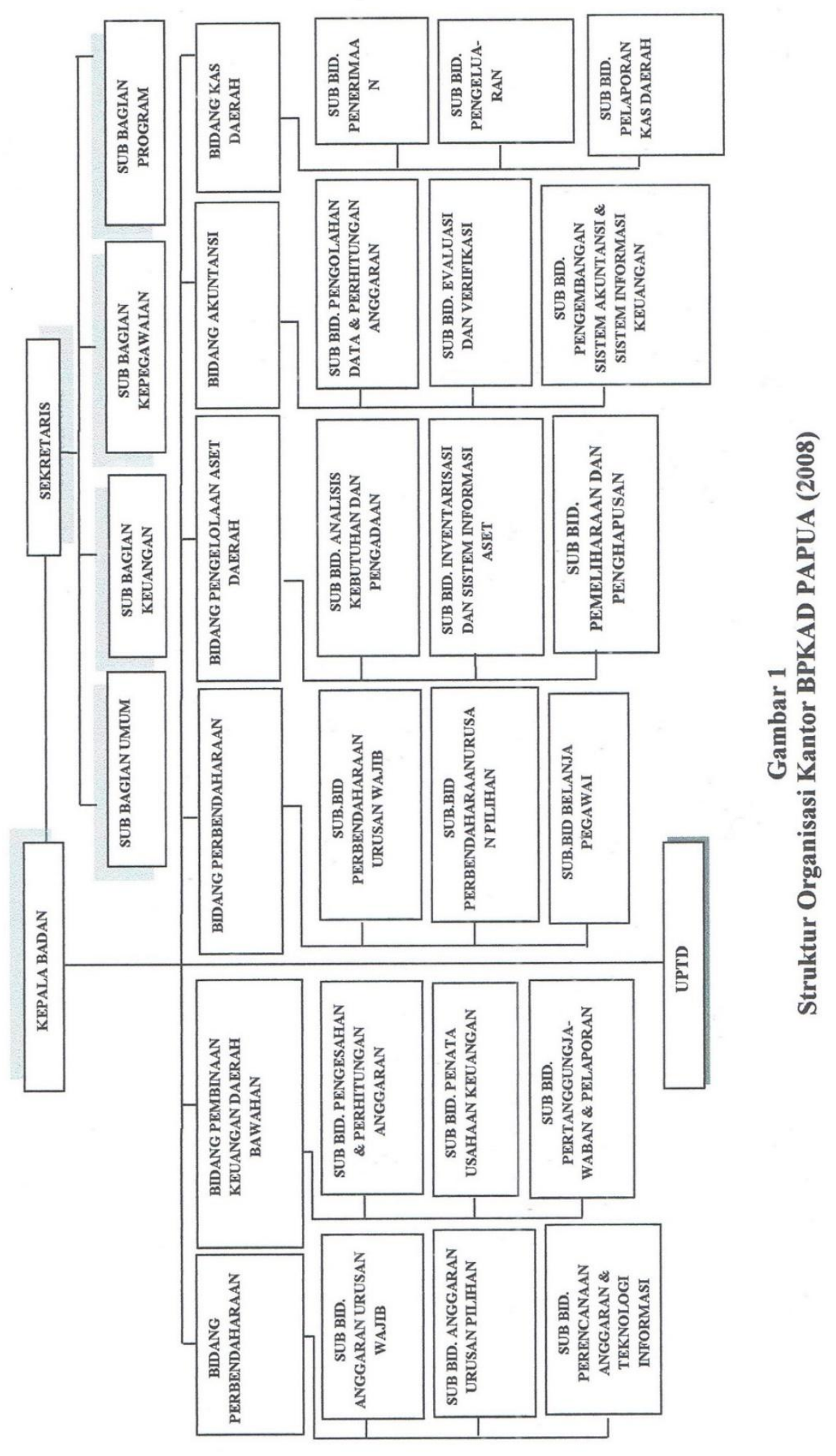


Bendahara penerimaan melakukan verifikasi kesesuaian jumlah uang yang diterima dengan dokumen SKP/SKR yang diterima dari pengguna anggaran. bendahara penerimaan menyerahkan uang beserta STS dan STBP/bukti lain yang sah kepada bank pemerintah yang telah ditunjuk dan selanjutnya bank membuatkan nota kredit dan mengotorisasi STS. Setelah itu STS dikembalikan kepada Bendahara penerimaan dan nota kredit disampaikan kepada PPKD selaku BUD.Bendahara penerimaan wajib mempertanggungjawabkan secara administratif pengelolaan keuangan yang menjadi tanggung jawabnya dengan menyampaikan laporan pertanggungjawaban berupa dokumen Surat Pertanggungjawaban (SPJ) yang disusun berdasarkan bukti-bukti transaksi sesuai dengan keadaan yang sebenarnya kepada pejabat penatausahaan keuangan satuan kerja perangkat daerah (PPK-SKPD) paling lambat tanggal lima bulan berikutnya. PPK-SKPD menyerahkan SPJ Penerimaan kepada Pengguna Anggaran paling lambat tanggal sepuluh bulan berikutnya. Berdasarkan tanggungjawab fungsional, Bendahara Penerimaan menyampaikan SPJ Penerimaan yang telah disahkan oleh Pengguna Anggaran kepada PPKD. Dalam rangka rekonsiliasi penerimaan, PPKD selaku BUD melakukan verifikasi, evaluasi dan analisis terhadap SPJ Penerimaan. Mekanisme dan tata caranya diatur dalam Peraturan Kepala Daerah.

\section{Prosedur Pelaksanaan dan Penatausahaan Pengeluaran/ Belanja Daerah}

Dalam pelaksanaan belanja daerah dilarang melakukan pengeluaran atas beban anggaran belanja daerah untuk tujuan yang tidak tersedia anggarannya dan atau yang tidak cukup tersedia anggarannya dalam APBD. Setiap pengeluaran harus didukung oleh bukti yang lengkap dan sah yang telah mendapat pengesahan oleh pejabat yang berwenang dan bertanggung jawab atas kebenaran material untuk setiap transaksi belanja daerah sesuai dengan keadaan yang sesungguhnya.

Penatausahaan Belanja Daerah dilakukan dalam beberapa proses yakni, Penyediaan Dana (SPD) dimana kuasa BUD menyerahkan rancangan Surat Penyediaan Dana (SPD) yang disusun berdasarkan dokumen Anggaran Kas Pemerintah Daerah dan DPA-SKPD sebanyak tiga rangkap kepada PPKD untuk selanjutnya dilakukan evaluasi. PPKD mengotorisasi rancangan SPD dan menyerahkan SPD kepada pihak-pihak terkait yaitu rangkap satu kepada Pengguna Anggaran, rangkap dua kepada Kuasa BUD sebagai arsip dan rangkap tiga sebagai arsip PPKD selaku BUD.

Dalam Pengajuan Permintaan Pembayaran (SPP) dan penerbitan Surat Perintah Membayar (SPM) pihak-pihak terkait menyiapkan dokumen-dokumen berikut sesuai dengan wewenang dan tanggungjawab masing-masing: (a) pengguna anggaran menyerahkan SPD kepada bendahara pengeluaran dan PPK-SKPD, (b) Bendahara Pengeluaran mengajukan permintaan pembayaran Surat Permintaan Pembayaran (SPP) UP/GU/TU dan LS kepada PPK-SKPD, (c)PPK-SKPD meneliti kelengkapan dokumen tersebut (dengan mengisi check list dan kesesuaiannya dengan 
SPD dan DPA-SKPD), (d) dibuatkan rancangan SPM-UP/GU/TU/NIHIL apabila dokumen SPP sudah dinyatakan lengkap.

Penerbitan Surat Perintah Pencairan Dana (SP2D) menggunakan dokumen Surat Perintah Membayar Uang Persediaan/Ganti Uang Persediaan/Tambahan Uang Persediaan/Nihil/Pembelian Barang dan Jasa Modal Serta Penggajian dan Tunjangan (SPM UP/GU/TU/Nihil/LS, Form chek list, register penerimaan SPM). SP2D hanya dapat diterbitkan jika pengeluaran yang diminta tidak melebihi kecukupan dana/pagu anggaran yang tersedia, didukung dengan kelengkapan dokumen sesuai peraturan perundangan.

Proses pelaksanaan/penggunaan dana adalah tahapan dimana Pengguna Anggaran melalui PPTK membelanjakan uang untuk membiayai program dan kegiatan yang telah ditetapkan dalam DPA-SKPD dan atau DPPA-SKPD. Pejabat Pengelola Teknis Kegiatan (PPTK) mengisi Nota Pencairan Dana (NPD) saat mengajukan permohonan dana untuk melaksanakan kegiatan tertentu kepada Pengguna Anggaran. Pengguna Anggaran selanjutnya membuatkan memo persetujuan kepada Bendahara Pengeluaran untuk mengeluarkan sejumlah dana yang dimaksud. Bendahara Pengeluaran mencatat pengeluaran tersebut pada buku pembantu panjar.

Sebagai pertanggungjawaban pengeluaran. bendahara pengeluaran melakukan pencatatan bukti-bukti transaksi pembelanjaan dana berdasarkan keadaan sesungguhnya dan untuk selanjutnya membuat SPJ Pengeluaran dan diserahkan kepada PPK-SKPD dan BUD paling lambat tangal lima bulan berikutnya. PPKSKPD memverifikasi SPJ Pengeluaran dengan meneliti kelengkapan dokumen laporan pertanggungjawaban dan keabsahan bukti-bukti pengeluaran yang dilaporkan, menguji kebenaran sesuai dengan SPM dan SP2D yang diterbitkan periode sebelumnya. Bila disetujui PPK-SKPD menyampaikan SPJ Pengeluaran kepada kepala SKPD paling lambat tanggal sepuluh bulan berikutnya. Kepala SKPD mengesahkan SPJ pengeluaran dan menyerahkan surat pengesahan SPJ Pengeluaran kepada Bendahara Pengeluaran.

\section{Perubahan Anggaran Pendapatan dan Belanja Daerah (APBD)}

Dalam melaksanakan Pasal 155 Permendagri No.13 Tahun 2006, perubahan APBD dapat dilakukan apabila terjadi pada keadaan-keadaan tertentu yang mengharuskan dilakukannya perubahan yang mana disajikan secara lengkap beserta penjelasannya.

Penyusunan Kebijakan Umum-Perubahan APBD (KUPA) dan Prioritas dan Plafon Anggaran Sementara Perubahan (PPAS-P).Rancangan awal KUPA disampaikan oleh Tim Anggaran Pemerintah Daerah (TAPD) pada Sekretaris Daerah selaku koordinator pengelola keuangan daerah danselanjutnya disetujui dan diserahkan kepada Gubernur.Selanjutnya Gubernur akan mengotorisasi dan menyerahkan kepada Dewan Perwakilan Rakyat Papua (DPRP) paling lambat minggu pertama bulan Agustus tahun anggaran berjalan.Kemudian dilakukan 
pembahasan dengan hasil dokumen KUPA dan Nota Kesepakatan KUPA. Selanjutnya TAPD menyusun rancangan awal PPASP berdasarkan KUPA dan Nota Kesepakatan KUPA. Proses yang dilakukan sama dengan proses penyusunan KUPA.

Penyusunan surat edaran tentang pedoman penyusunan RKA-SKPD. Penyusunan pedoman mengacu pada KUPA dan Prioritas dan Plafon Anggaran Perubahan (PPAP) yang telah disepakati. TAPD menyerahkan rancangan awal surat edaran Gubernur tentang pedoman penyusunan rencana kerja dan anggaran SKPD (RKA-SKPD) pada Sekretaris Daerah dan setelah disetujui oleh Sekretaris Daerah meneruskan kepada Gubernur. Rancangan Surat Edaran (SE) Gubernur tentang Pedoman Penyusunan RKA-SKPD yang sudah diotorisasi oleh Gubernur menjadi SE Gubernur tentang Pedoman Penyusunan RKA-SKPD yang oleh Sekretaris Daerah selanjutnya disebarkan kepada setiap SKPD.

Terkait penyusunan RKA-SKPD, DPPA-SKPD dan penyiapan Rancangan Peraturan Daerah (RAPERDA) tentang Perubahan APBD, Surat Edaran Gubernur tentang Pedoman Penyusunan RKA-SKPD diberikan kepada SKPD. Berdasarkan SE tersebut SKPD menyusun RKA-SKPD dan/atau DPPA-SKPD masing-masing meliputi Rincian Anggaran Pendapatan, Rincian Anggaran Belanja Tidak Langsung, Rincian Anggaran Belanja Langsung, Rincian Penerimaan Pembiayaan Daerah, Rincian Pengeluaran Pembiayaan Daerah dengan menggunakan form DPPA-SKPD. Dokumen-dokumen ini kemudian diserahkan kepada PPKD untuk penyusunan Raperda Perubahan APBD dan selanjutnya dilakukan pembahasan dengan TAPD. Pembahasan ini bertujuan untuk dapat menelaah kesesuaian antara RKA-SKPD dan DPPA-SKPD dengan KUPA PPAP dan dokumen lainnya serta singkronisasi program dan kegiatan antar SKPD. PPKD selanjutnya menyerahkan Raperda APBD yang telah dikompilasi (atas RKA-SKPD dan DPPA-SKPD) beserta lampiran dan Nota Keuangan kepada Sekretaris Daerah dan selanjutnya Sekretaris Daerah menyerahkan kepada gubernur. Selanjutnya Raperda tersebut disosialisasikan terlebih dahulu kepada masyarakat sebelum diserahkan kepada DPRD.

Gubernur menyerahkan Raperda Perubahan APBD beserta lampiran dan Nota Keuangan kepada DPRP paling lambat minggu kedua September tahun anggaran berjalan. Raperda Perubahan APBD dibahas dan disetujui bersama oleh pemerintah daerah Papua dan DPRP dan ditetapkan dengan peraturan daerah. Selanjutnya DPRP menyerahkan persetujuan bersama tersebut kepada PPKD. PPKD menyiapkan Rancangan peraturan Gubernur tentang Penjabaran Perubahan APBD dan diserahkan kepada Gubernur. Selanjutnya gubernur akan menyerahkan kepada Menteri Dalam Negeri.Menteri Dalam Negeri akan mengevaluasi kesesuaian antara kebijakan daerah dankebijakan nasional serta,keserasian antara kepentinganpublik dan kepentingan aparatur.

\section{Pertanggungjawaban Pelaksanaan APBD}

Gubernur menyampaikan laporan keuangan pemerintah daerah kepada BPK paling lambat tiga bulan setelah tahun anggaran berakhir untuk memenuhi prinsip akuntabilitas dan transparansi dalam pengelolaan dan pertanggungjawaban 
pelaksanaan keuangan daerah. Pemeriksaan BPK terhadap laporan keuangan pemerintah tergolong jenis pemeriksaan keuangan yaitu pemeriksaan atas laporan keuangan untuk memberikan opini. Opini diberikan berdasarkan kriteria-kriteria yang meliputi kesesuaian dengan standar akuntansi pemerintahan, kecukupan pengungkapan, kepatuhan terhadap peraturan perundang-undangan dan efektivitas sistem pengendalian intern (pasal 16 ayat (1) UU No.15 Tahun 2004 tentang Pemeriksaan Pengelolan dan Tanggung Jawab Keuangan Negara/Daerah). Laporan keuangan yang diperiksa mencakup Laporan Realisasi Anggaran(LRA), Laporan Arus Kas(LAK), Neraca dan Catatan Atas Laporan Keuangan (CALK) yang dilampiri dengan ikhtisar realisasi kinerja dan laporan keuangan perusahaan daerah serta Surat Pernyataan Gubernur yang menyatakan pengelolaan APBD yang menjadi tanggung jawabnya telah diselenggarakan berdasarkan sistem pengendalian intern yang memadai.

BPK melakukan pemeriksaan paling lambat dua bulan setelah diterima laporan keuangan. Selanjutnya Gubernur menyusun dan menyerahkan Raperda pertanggungjawaban pelaksanaan APBD. Raperda meliputi LRA, LAK, Neracadan CALK serta dilampiri dengan Laporan Hasil Pemeriksaan yang telah diperiksa BPK diserahkan kepada DPRP dan dilakukan pembahasan (Pasal 102 ayat (2) dan ayat (3) PP No.58 Tahun 2005).

Raperda disampaikan kepada Menteri Dalam Negeri untuk dievaluasi. Menteri Dalam Negeri mengevaluasi Raperda tentang pertanggungjawaban pelaksanaan APBD untuk disesuaikan dengan kepentingan umum dan peraturan perundang-undangan yang lebih tinggi. Bila hasil evaluasi sudah sesuai maka Menteri Dalam Negeri menetapkan menjadi peraturan daerah dan peraturan Gubernur.

\section{Kesesuaian POS Pengelolaan Keuangan Daerah Provinsi Papua terhadap Permendagri No.13 Tahun 2006.}

Berdasarkan hasil wawancara yang dilakukan kepada Sekretaris BPKAD terkait kesesuaian POS Pengelolaan Keuangan Daerah dengan Permendagri No.13 Tahun 2006, dapat disimpulkan bahwa POS yang disusun dan diterapkan di Pemda Papua telah mengacu pada Permendagri tersebut. Adapun kesesuaian tersebut adalah sebagai berikut.

1. Prosedur Pelaksanaan dan Penatausahaan APBD disusun dengan mengacu pada pasal 122 Permendagri No.13 Tahun 2006, yang menyatakan dalam pelaksanaan dan penatausahaan penerimaan daerah dan pengeluaran daerah dalam rangka pelaksanaan urusan pemerintahan daerah dikelola dalam APBD.

2. Prosedur Perubahan Pendapatan dan Belanja (APBD) mengacu pada pasal 155 Permendagri No.13 Tahun 2006, yang menyatakan perubahan terhadap APBD hanya dapat dilakukan apabila terjadi keadaan-keadaan tertentu yang mengharuskan dilakukannya perubahan yang disajikan secara lengkap bersama penjelasannya. 
3. Prosedur Pertanggungjawaban Pelaksanaan APBD mengacu pada Pasal 296 Permendagri No.13 Tahun 2006 yang menyatakan bahwa kepala daerah menyusun laporan keuangan pemerintah daerah dengan menggabungkan laporanlaporan keuangan SKPD dalam rangka memenuhi pertanggungjawaban.

\section{Kepatuhan Penerapan Prosedur Operasional Standar Pengelolaan Keuangan Daerah Provinsi Papua}

Berdasarkan penjelasan sebelumnya, POS Pengelolaan Keuangan Daerah Provinsi Papua telah mengacu pada Permendagri No.13 Tahun 2006. Selanjutnya dilakukan evaluasi kepatuhan penerapan POS Pengelolaan Keuangan Daerah Provinsi Papua tersebut. Hasil evaluasi penerapan POS Pengelolaan Keuangan Daerah Provinsi Papua tersebut diringkas dalam Tabel 1.

Berdasarkan Tabel 1, meskipun penerapan POS Pengelolaan Keuangan Daerah Provinsi Papua sebagian besar telah dilakukan, namun masih terdapat beberapa ketidaksesuaian dalam Pelaksanaan dan Penatausahaan APBD. Ketidaksesuaian yang terjadi yaitu: (a) pembayaran kepada bendahara penerimaan tidak sesuai dengan SKR, namun Bendahara Penerimaan tetap mencatatnya sehingga seringkali terdapat selisih antara dokumentasi bendahara dengan saldo kas; Bendahara penerimaan sering tidak melakukan verifikasi, (b) bendahara penerimaan tidak tepat waktu dalam menyampaikan SPJ kepada PPK-SKPD, karena tidak tertibnya penyimpanan bukti. Sehingga PPK-SKPD terlambat dalam menyerahkan SPJ Penerimaan. Akhirnya pengguna anggaran tidak tepat waktu dalam melakukan otorisasi dan dalam menyerahkan SPJ Penerimaan kepada BUD, (c) dokumen yang diajukan bendahara pengeluaran tidak lengkap, (d) bendahara menerbitkan SP2D untuk pengeluaran yang melebihi Pagu Anggaran, (e) bendahara pengeluaran terlambat menyusun dan membuat SPJ pengeluaran. Sehingga PPK-SKPD terlambat dalam memverifikasi SPJ tersebut.

Tabel 1

Evaluasi Penerapan Prosedur Operasional Standar Pengelolaan Keuangan Daerah Provinsi Papua

\begin{tabular}{|c|c|c|c|c|c|}
\hline \multirow[t]{2}{*}{ No. } & \multirow[t]{2}{*}{ POS } & \multirow[t]{2}{*}{ Point dalam POS } & \multicolumn{2}{|c|}{ Realisasi } & \multirow[t]{2}{*}{ Keterangan } \\
\hline & & & Ya & Tdk & \\
\hline \multirow[t]{13}{*}{1} & Pelaksanaan dan & a. Pejabat Pengelola Keuangan Daerah & $\sqrt{ }$ & & Paling lambat 3 (tiga) hari \\
\hline & Penatausahaan & (PPKD) membuat surat pemberitahuan & & & setelah APBD ditetapkan \\
\hline & APBD & kepada SKPD untuk menyusun rancangan & & & \\
\hline & & Dokumen Pelaksanaan Anggaran (DPA- & & & \\
\hline & & SKPD) & & & \\
\hline & & b.SKPD menyerahkan rancangan DPA- & $\sqrt{ }$ & & Rancangan DPA-SKPD sebagai \\
\hline & & SKPD dan rancangan Anggaran Kas & & & dasar disusunnya rancangan \\
\hline & & SKPD yang disusunnya kepada PPKD & & & Anggaran Kas SKPD. \\
\hline & & (Kepala SKPD) & & & Keduanya disusun paling \\
\hline & & & & & $\begin{array}{l}\text { lambat } 6 \text { (enam) hari kerja } \\
\text { setelah pemberitahuan PPKD }\end{array}$ \\
\hline & & c.Verifikasi rancangan DPA-SKPD \& & $\sqrt{ }$ & & Diselesaikan paling lambat 15 \\
\hline & & rancangan Anggaran Kas SKPD bersama- & & & (lima belas) hari kerja sejak \\
\hline & & sama SKPD oleh Tim Anggaran & & & ditetapkannya Peraturan \\
\hline
\end{tabular}




\begin{tabular}{lccc}
\hline No. & POS & Point dalam POS & \multicolumn{2}{c}{ Kealisasi } & \\
\cline { 2 - 3 } & & Ya Tdk & \\
\hline & Pemerintah Daerah (TAPD) & Gubernur tentang Penjabaran \\
& & APBD
\end{tabular}

Tabel 1 (Lanjutan)

Evaluasi Penerapan Prosedur Operasional Standar Pengelolaan Keuangan Daerah Provinsi Papua

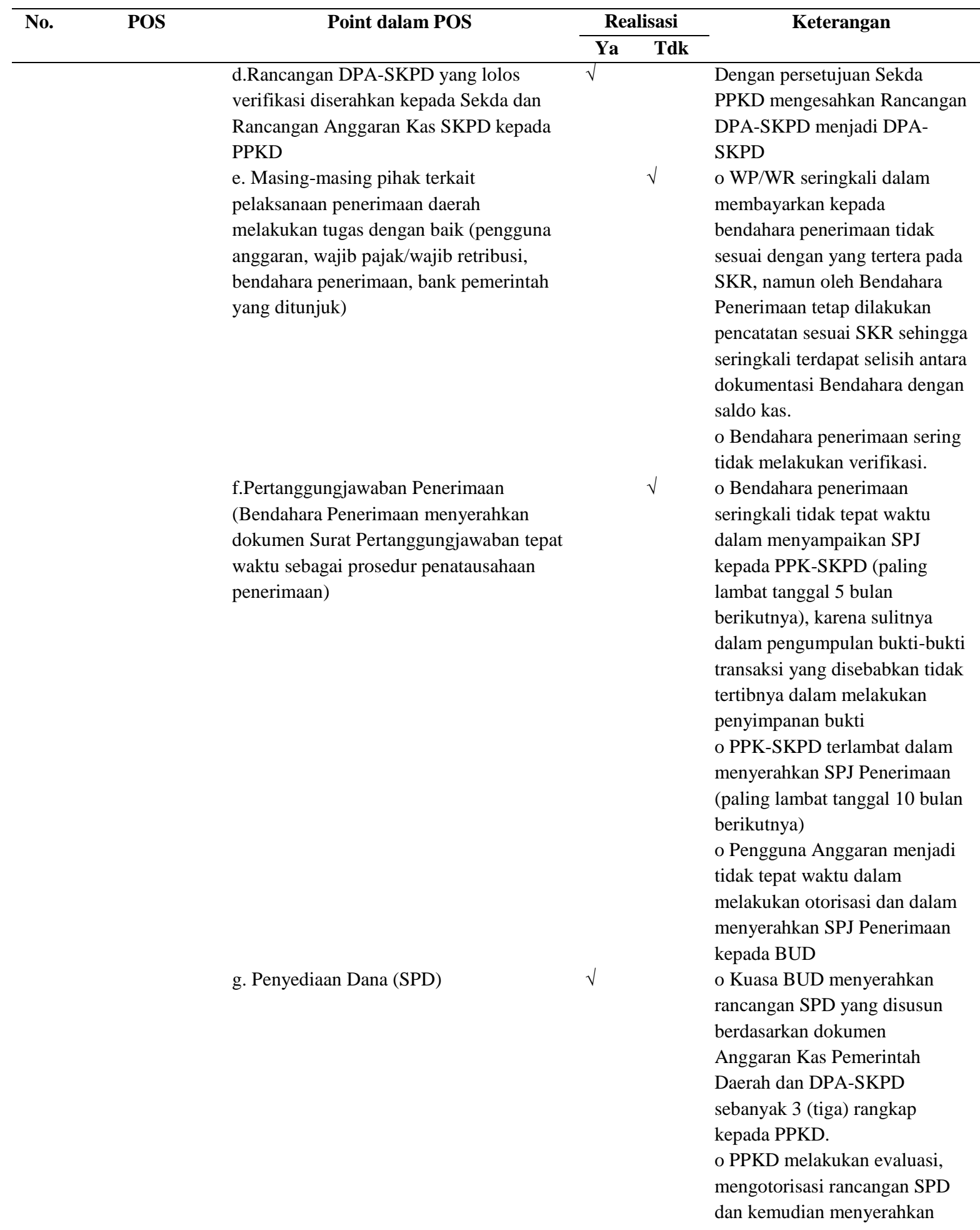


Tabel 1 (Lanjutan)

Evaluasi Penerapan Prosedur Operasional Standar Pengelolaan Keuangan Daerah Provinsi Papua

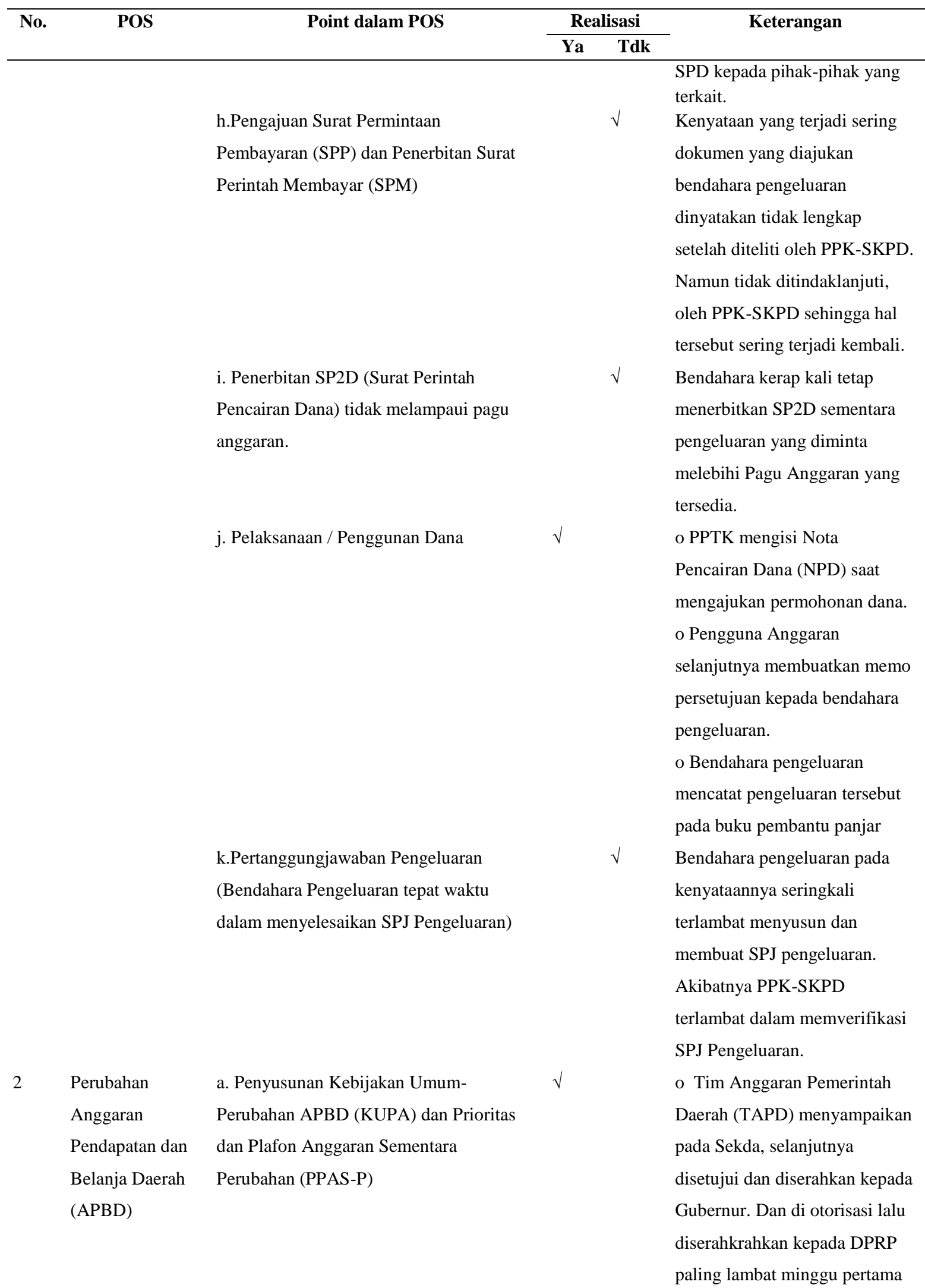


Tabel 1 (Lanjutan)

Evaluasi Penerapan Prosedur Operasional Standar Pengelolaan Keuangan Daerah Provinsi Papua

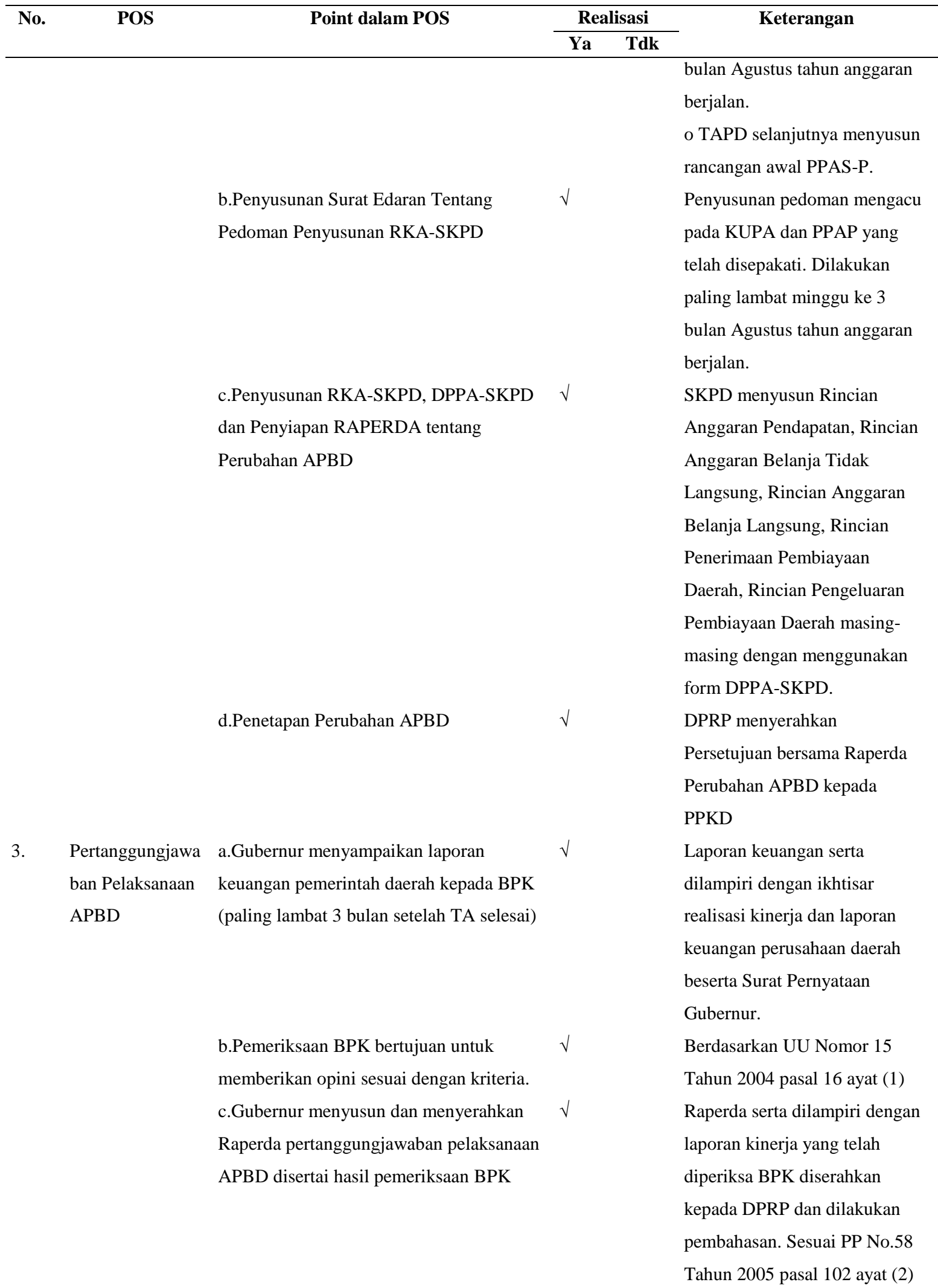


Tabel 1 (Lanjutan)

Evaluasi Penerapan Prosedur Operasional Standar Pengelolaan Keuangan Daerah Provinsi Papua

\begin{tabular}{|c|c|c|c|c|c|}
\hline \multirow[t]{2}{*}{ No. } & \multirow[t]{2}{*}{ POS } & \multirow[t]{2}{*}{ Point dalam POS } & \multicolumn{2}{|c|}{ Realisasi } & \multirow[t]{2}{*}{ Keterangan } \\
\hline & & & $\mathbf{Y a}$ & Tdk & \\
\hline & & d.Raperda disampaikan kepada Menteri & \multirow[t]{7}{*}{$\sqrt{ }$} & & Menteri Dalam Negeri \\
\hline & & Dalam Negeri untuk dievaluasi & & & mengevaluasi Raperda tentang \\
\hline & & & & & pertanggungjawaban \\
\hline & & & & & pelaksanaan APBD disesuaikan \\
\hline & & & & & dengan kepentingan umum dan \\
\hline & & & & & peraturan perundang-undangan \\
\hline & & & & & yang lebih tinggi. \\
\hline
\end{tabular}

Ketidakpatuhan POS Pengelolaan Keuangan Daerah Provinsi Papua tersebut juga tercermin dalam temuan BPK. Evaluasi atas temuan BPK terhadap ketidakpatuhan POS Pengelolaan Keuangan Daerah Provinsi Papua disajikan dalam Tabel 2.

Berdasarkan Tabel 2, ketidakpatuhan POS Pengelolaan Keuangan Daerah Provinsi Papua terdapat pada pelaksanaan dan penatausahaan penerimaan/ pengeluaran daerah serta pertanggungjawaban penerimaan/pengeluaran daerah. Dengan demikian, realisasi penerapan prosedur operasional standar pengelolaan keuangan daerah Provinsi Papua secara keseluruhan, masih terdapat beberapa ketidakpatuhan yang salah satu penyebabnya adalah kelemahan dalam sistem pengendalian intern (SPI). Contoh-contoh ketidakpatuhan POS pengelolaan keuangan Pemerintah Provinsi Papua adalah sebagai berikut.

1. Banyaknya ketidaktepatan waktu dalam pelaksanaan dan penatausahaan serta pertanggungjawaban transaksi oleh bendahara penerimaan dan bendahara pengeluaran.

2. Ketidaksesuaian pencatatan antara dokumen dengan kondisi yang sebenarnya oleh bendahara penerimaan.Pihak berwenang juga tidak melakukan verifikasi terhadap dokumen yang tersedia.

3. Bendahara penerimaan dan/atau bendahara pengeluaran tidak lengkap dalam menyiapkan dokumen-dokumen pendukung dan tidak melakukan pencatatan atas bukti-bukti transaksi yang digunakan dalam penatausahaan.

4. Bendahara Penerimaan dan/atau Bendahara Pengeluaran banyak tidak melakukan pertanggungjawaban atas transaksi yang terjadi.

5. Dalam pelaksanaan penerimaan dan pengeluaran daerah, bendahara terkait tidak melakukan melalui rekening Kas Umum Daerah.

Dari hasil evaluasi tersebut, hambatan yang memengaruhiketidakpatuhan pelaksanaan POS Pengelolaan Keuangan Daerah Provinsi Papua adalah sebagai berikut:

1. lemahnya Sistem Pengendalian Intern pemerintah, antara lain mengakibatkan beberapa pengeluaran belum dibuat pertanggungjawaban; penerimaan 
diterima tidak melalui rekening kas daerah;beberapa transaksi dicatat tidak sesuai; dana tidak maksimal dimanfaatkan; bukti dan dokumen tidak lengkap; penyajian persediaan dan peralatan tidak didasarkan perhitungan fisik, tidak dapat ditelusuri keberadaannya; beberapa transaksi melampaui pagu anggaran yang ditetapkan; penyajian utang/piutang pajak tidak menggambarkan kondisi yang sebenarnya;

2. kurangnya pembinaan dan pengawasan pengelolaan keuangan daerah, antara lain mengakibatkan sering terjadi ketidaktepatan waktu pemrosesan yang dikarenakan sulitnya memperoleh dan menelusuri bukti-bukti transaksi. Selain itu sering terjadi ketidaksesuaian pencatatan terhadap transaksi dengan keadaan yang sesungguhnya.

Tabel 2

Evaluasi atas Temuan BPK terhadap Ketidakpatuhan POS Pengelolaan Keuangan Daerah Provinsi Papua

\begin{tabular}{|c|c|c|c|c|}
\hline No. & $\begin{array}{c}\text { Tahun } \\
\text { Anggaran }\end{array}$ & Temuan BPK & $\begin{array}{c}\text { Ketidakpatuhan } \\
\text { POS }\end{array}$ & Keterangan POS \\
\hline 1. & 2007 & $\begin{array}{l}\text { Pengeluaran tahun } 2004 \\
\& 2006 \text { yang hingga } 2007 \\
\text { belum dibuat } \\
\text { pertanggungjawabannya } \\
\text { oleh Bendahara } \\
\text { Pengeluaran. }\end{array}$ & $\begin{array}{l}\text { Pertanggungjawaban } \\
\text { pengeluaran daerah }\end{array}$ & $\begin{array}{l}\text { Dalam setiap transaksi } \\
\text { pengeluaran Bendahara } \\
\text { Pengeluaran harus } \\
\text { melakukan pencatatan bukti- } \\
\text { bukti pengeluaran, } \\
\text { selanjutnya melalui dokumen } \\
\text { tersebut Bendahara } \\
\text { Pengeluaran wajib membuat } \\
\text { SPJ pegeluaran }\end{array}$ \\
\hline 2. & 2007 & $\begin{array}{l}\text { Penerimaan bagi hasil } \\
\text { PBB digunakan langsung } \\
\text { sebagai tambahan upah } \\
\text { pungut diterima tidak } \\
\text { melalui rekening kas } \\
\text { daerah melainkan melalui } \\
\text { rekening Bendaharawan } \\
\text { Khusus Pajak Bumi } \\
\text { Bangunan Pemerintah } \\
\text { Papua }\end{array}$ & $\begin{array}{l}\text { Pelaksanaan dan } \\
\text { penatausahaan } \\
\text { penerimaan daerah }\end{array}$ & $\begin{array}{l}\text { Semua penerimaan daerah } \\
\text { apabila berbentuk uang harus } \\
\text { segera disetor ke Kas Umum } \\
\text { Daerah oleh Bendahara } \\
\text { Penerimaan. }\end{array}$ \\
\hline 3. & 2007 & $\begin{array}{l}\text { Penerimaan retribusi yang } \\
\text { tidak sesuai SKR namun } \\
\text { oleh Bendahara } \\
\text { Penerimaan dicatat sesuai } \\
\text { dengan yang tertera di } \\
\text { SKR dalam } \\
\text { pertanggungjawaban. }\end{array}$ & $\begin{array}{l}\text { Pertanggungjawaban } \\
\text { penerimaan daerah }\end{array}$ & $\begin{array}{l}\text { Bendahara penerimaan } \\
\text { melakukan verifikasi } \\
\text { kesesuaian jumlah uang yang } \\
\text { diterima dengan SKR/SKP } \\
\text { yang diterima dari pengguna } \\
\text { anggaran sebelum } \\
\text { melakukan penyetoran dan } \\
\text { juga sebelum menyiapkan } \\
\text { dokumen SPJ. }\end{array}$ \\
\hline
\end{tabular}




\section{Tabel 2 (Lanjutan) \\ Evaluasi atas Temuan BPK terhadap Ketidakpatuhan POS Pengelolaan Keuangan Daerah Provinsi Papua}

\begin{tabular}{|c|c|c|}
\hline No. & $\begin{array}{c}\text { Tahun } \\
\text { Anggaran }\end{array}$ & Temuan BPK \\
\hline 4 & 2008 & $\begin{array}{l}\text { Dana Respek (Rencana } \\
\text { Strategi Pembangunan } \\
\text { Kampung) Tahun } 2007 \\
\text { tidak maksimal } \\
\text { dimanfaatkan (tidak } \\
\text { sesuai dengan yang } \\
\text { ditetapkan dalam DPA- } \\
\text { SKPD dan atau DPPA- } \\
\text { SKPD). }\end{array}$ \\
\hline 5 & 2008 & $\begin{array}{l}\text { Aset Pemerintah Papua } \\
\text { yang belum dicatat saat } \\
\text { pengeluaran. }\end{array}$ \\
\hline 6 & 2009 & $\begin{array}{l}\text { Penyajian persediaan alat } \\
\text { kesehatan pakai habis \& } \\
\text { obat tidak didasarkan } \\
\text { perhitungan fisik (Tidak } \\
\text { sesuai dengan DPA- } \\
\text { SKPD). Dan administrasi } \\
\text { kartu persediaan tidak } \\
\text { tertib }\end{array}$ \\
\hline
\end{tabular}

Nilai aset tetap tidak didukung \& tidak disertai dengan dokumen yang memadai

Penyertaan modal pemerintah Provinsi Papua pada PT EMKL

\begin{tabular}{ll}
\multicolumn{1}{c}{$\begin{array}{c}\text { Ketidakpatuhan } \\
\text { POS }\end{array}$} & \multicolumn{1}{c}{ Keterangan POS } \\
\hline Pelaksanaan dan & Pelaksanaan Respek harus \\
penatausahaan & sesuai dengan yang \\
pengeluaran daerah & ditetapkan di dalam DPA- \\
(Pelaksanaan/ & SKPD (Dokumen \\
penggunaan dana). & Pelaksanaan Anggaran)
\end{tabular}

Pelaksanaan dan penatausahaan pengeluaran (Pertanggungjawaban Bendahara Pengeluaran) Pelaksanaan dan penatausahaan pengeluaran daerah

Segala transaksi pengeluaran oleh Bendahara Pengeluaran harus dilakukan pencatatan yang digunakan sebagai bukti dalam pertanggungjawaban Bendahara Pengeluaran melaksanakan pembayaran dari uang yang dikelolanya setelah :

a. Meneliti kelengkapan perintah pembayaran yang diterbitkan oleh pengguna anggaran / kuasa pengguna anggaran.

b. Menguji kebenaran perhitungan tagihan yang tercantum dalam perintah pembayaran dengan keadaan yang sebenarnya.

c. Menguji ketersediaan dana.

d. Menguji Kesesuaian dengan DPA

Bendahara pengeluaran harus menyusun dengan baik administrastif atas segala transaksi yang dilakukan, didukung dengan bukti yang lengkap dan sah dengan cara membuat dan menyampaikan laporan pertanggungjawaban pengeluaran.

Pelaksanaan dan penatausahaan penerimaan daerah

Dimana setiap transaksi penerimaan daerah yang terjadi oleh Bendahara Penerimaan harus menyiapkan bukti-bukti yang lengkap dan sah.

Pelaksanaan dan penatausahaan penerimaan daerah
Setiap transaksi penerimaan daerah harus selalu didukung oleh bukti yang lengkap dan 
Tabel 2 (Lanjutan)

Evaluasi atas Temuan BPK terhadap Ketidakpatuhan POS Pengelolaan Keuangan Daerah Provinsi Papua

\begin{tabular}{|c|c|c|c|c|}
\hline No. & $\begin{array}{c}\text { Tahun } \\
\text { Anggaran } \\
\end{array}$ & Temuan BPK & $\begin{array}{c}\text { Ketidakpatuhan } \\
\text { POS } \\
\end{array}$ & Keterangan POS \\
\hline & & $\begin{array}{l}\text { VP tidak dilengkapi } \\
\text { dengan bukti penyertaan } \\
\text { modal }\end{array}$ & & sah \\
\hline 9 & 2009 & $\begin{array}{l}\text { Penggunaan dana } \\
\text { kegiatan peningkatan } \\
\text { penyiaran TV PAPUA } \\
\text { belum } \\
\text { dipertanggungjawabkan }\end{array}$ & $\begin{array}{l}\text { Pertanggungjawaban } \\
\text { pengeluaran daerah }\end{array}$ & $\begin{array}{l}\text { Dalam setiap transaksi } \\
\text { pengeluaran Bendahara } \\
\text { Pengeluaran harus } \\
\text { melakukan pencatatan bukti- } \\
\text { bukti pengeluaran, } \\
\text { selanjutnya melalui dokumen } \\
\text { tersebut Bendahara } \\
\text { Pengeluaran wajib membuat } \\
\text { SPJ pegeluaran }\end{array}$ \\
\hline \multirow[t]{2}{*}{10} & 2009 & $\begin{array}{l}\text { Belanja modal pada } \\
\text { beberapa biro belum } \\
\text { didukung dan disertai } \\
\text { bukti yang lengkap }\end{array}$ & $\begin{array}{l}\text { Pelaksanaan dan } \\
\text { penatausahaan } \\
\text { pengeluaran daerah }\end{array}$ & $\begin{array}{l}\text { Setiap penerimaan daerah } \\
\text { yang terjadi harus dapat } \\
\text { didukung dengan bukti yang } \\
\text { lengkap dan memadai yang } \\
\text { telah di sahkan }\end{array}$ \\
\hline & & $\begin{array}{l}\text { Pertanggungjawaban } \\
\text { hanya berupa disposisi \& } \\
\text { kuitansi tanda terima } \\
\text { tanpa disertai bukti SPJ }\end{array}$ & $\begin{array}{l}\text { Pertanggungjawaban } \\
\text { pengeluaran daerah }\end{array}$ & $\begin{array}{l}\text { Bendahara pengeluaran harus } \\
\text { melakukan pencatatan bukti- } \\
\text { bukti pengeluaran dan harus } \\
\text { membuat SPJ pengeluaran } \\
\text { sebagai bukti } \\
\text { pertanggungjawaban }\end{array}$ \\
\hline 11 & 2010 & $\begin{array}{l}\text { Penyajian persediaan obat } \\
\text { dan alat kesehatan tidak } \\
\text { dapat ditelusuri } \\
\text { keberadaannya }\end{array}$ & $\begin{array}{l}\text { Pertanggungjawaban } \\
\text { pengeluaran daerah }\end{array}$ & $\begin{array}{l}\text { Bendahara Pengeluaran } \\
\text { harus mencatat bukti-bukti } \\
\text { sesuai dengan transaksi yang } \\
\text { benar-benar dilakukan (ada } \\
\text { kesesuaian), yang oleh PPK- } \\
\text { SKPD dapat ditelusuri pada } \\
\text { waktu memverifikasi SPJ } \\
\text { Pengeluaran. }\end{array}$ \\
\hline 12 & 2010 & $\begin{array}{l}\text { Pemerintah Provinsi } \\
\text { Papua tidak dapat } \\
\text { menyediakan data secara } \\
\text { lengkap mengenai } \\
\text { kapitalisasi aset tetap } \\
\text { dalam } \\
\text { pertanggungjawaban }\end{array}$ & $\begin{array}{l}\text { Pertanggungjawaban } \\
\text { penerimaan daerah }\end{array}$ & $\begin{array}{l}\text { Segala transaksi penerimaan } \\
\text { harus didukung oleh bukti } \\
\text { yang lengkap dan memadai } \\
\text { yang telah disahkan oleh } \\
\text { pejabat yang berwenang dan } \\
\text { bertanggungjawab }\end{array}$ \\
\hline \multirow[t]{2}{*}{13} & 2010 & $\begin{array}{l}\text { Penyajian belanja barang } \\
\text { pada beberapa SKPD } \\
\text { tidak didukung dengan } \\
\text { bukti yang lengkap. }\end{array}$ & $\begin{array}{l}\text { Pertanggungjawaban } \\
\text { pengeluaran daerah }\end{array}$ & $\begin{array}{l}\text { Sebelum menyusun dokumen } \\
\text { SPJ Pengeluaran dan } \\
\text { sebelum menyerahkan SPJ } \\
\text { kepada PPK-SKPD dan } \\
\text { BUD, bendahara seharusnya } \\
\text { melakukan pencatatan } \\
\text { terhadap bukti-bukti yang } \\
\text { ada dan melakukan } \\
\text { verifikasi. }\end{array}$ \\
\hline & & $\begin{array}{l}\text { Transaksi tersebut } \\
\text { melampaui pagu } \\
\text { anggaran yang ditetapkan }\end{array}$ & $\begin{array}{l}\text { Pelaksanaan dan } \\
\text { penatausahaan } \\
\text { pengeluaran daerah } \\
\text { (penerbitan SP2D) }\end{array}$ & $\begin{array}{l}\text { Penerbitan Surat Perintah } \\
\text { Pencairan Dana (SP2D) } \\
\text { seharusnya tidak dapat } \\
\text { dilakukan untuk transaksi }\end{array}$ \\
\hline
\end{tabular}


Tabel 2 (Lanjutan)

Evaluasi atas Temuan BPK terhadap Ketidakpatuhan POS

Pengelolaan Keuangan Daerah Provinsi Papua

\begin{tabular}{|c|c|c|c|c|}
\hline No. & $\begin{array}{c}\text { Tahun } \\
\text { Anggaran }\end{array}$ & Temuan BPK & $\begin{array}{c}\text { Ketidakpatuhan } \\
\text { POS }\end{array}$ & Keterangan POS \\
\hline & & & & $\begin{array}{l}\text { tersebut sebab SP2D hanya } \\
\text { dapat diterbitkan jika } \\
\text { pengeluaran yang diminta } \\
\text { tidak melebihi pagu } \\
\text { anggaran sertai didukung } \\
\text { dengan kelengkapan } \\
\text { dokumen. }\end{array}$ \\
\hline 14 & 2010 & $\begin{array}{l}\text { Penyajian piutang pajak } \\
\text { dan piutang retribusi } \\
\text { tidak menggambarkan } \\
\text { kondisi yang sebenarnya }\end{array}$ & $\begin{array}{l}\text { Pertanggungjawaban } \\
\text { penerimaan daerah }\end{array}$ & $\begin{array}{l}\text { Kondisi tersebut seharusnya } \\
\text { dapat diketahui pada saat } \\
\text { PPK-SKPD melakukan } \\
\text { verifikasi, evaluasi dan } \\
\text { analisis terhadap SPJ } \\
\text { penerimaan sebelum } \\
\text { diserahkan kepada PPKD } \\
\text { selaku BUD }\end{array}$ \\
\hline 15 & 2010 & $\begin{array}{l}\text { Saldo utang perhitungan } \\
\text { pihak ketiga tidak dapat } \\
\text { diyakini kewajarannya }\end{array}$ & $\begin{array}{l}\text { Pertanggungjawaban } \\
\text { pengeluaran daerah }\end{array}$ & $\begin{array}{l}\text { Segala transaksi pengeluaran } \\
\text { daerah harus didukung } \\
\text { dengan bukti yang lengkap } \\
\text { dan memadai sesuai dengan } \\
\text { keadaan yang sebenarnya } \\
\text { dan telah disahkan }\end{array}$ \\
\hline
\end{tabular}

Sumber Data: Biro Keuangan 2007 dan BPKAD 2010

\section{SIMPULAN}

Berdasarkan analisis data, peneliti dapat menarik simpulan sebagai berikut.

1. Prosedur operasional standar pengelolaan keuangan daerah yang diterapkan di Provinsi Papua meliputi sistem dan prosedur pelaksanaan dan penatausahaan APBD, sistem dan prosedur perubahan APBD dan sistem dan prosedur pertanggungjawaban APBD. Ketiga prosedur operasional standar tersebut disusun dengan mengacu kepada Permendagri No.13 Tahun 2006 dan Permendagri No.59 Tahun 2007 atas perubahan Permendagri No.13 Tahun 2006 yang merupakan ketentuan lanjutan dari PP No.58 Tahun 2005.

2. Dalam realisasi, POSPengelolaan Keuangan Daerah yang berlaku di Provinsi Papua yang saat ini berlaku belum sepenuhnya dipatuhi dengan baik. Adapun ketidakpatuhan POS yang menyebabkan penurunan opini BPK antara lain dikarenakan lemahnya sistem pengendalian internal, yang dapat dilihat dari ketidaksesuaian antara catatan dengan keadaan yang sesungguhnya oleh bendahara terkait, ketidaktepatan waktu dalam menghasilkan laporan keuangan dikarenakan pengumpulan dokumen-dokumen yang belum lengkap buktinya. Selain itu beberapa transaksi belum terdapat pertanggungjawabannya. 
3. Dalam kepatuhan penerapan POS, hambatan yang dihadapi adalah lemahnya sistem pengendalian intern di pemerintah Provinsi Papua serta kurangnya pembinaan dan pengawasan pengelolaan keuangan daerah.

Dengan dipatuhinya POS pengelolaan keuangan daerah di Provinsi Papua, yang didukung dengan sistem pengendalian intern memadai akan memberikan keyakinan mengenai pencapaian tujuan pemerintah daerah yang tercermin dari keandalan laporan keuangan daerah, efisiensi dan efektivitas pelaksanaan program dan kegiatan yang dapat dipertangungjawabkan.

\section{SARAN}

Untuk mengefektifkan kepatuhan prosedur terhadap proses pengelolaan keuangan daerah di Provinsi Papua kedepannya, Pemprov Papua disarankan dapat melakukan langkah-langkah nyata sebagai berikut:

1. Pemantauan secara periodik (berkelanjutan) terhadap sistem pengendalian intern. Pemantauan meliputi penilaian atas kualitas kinerja pengendalian intern untuk menentukan apakah operasi pengendalian memerlukan modifikasi atau perbaikan. Pemantauan secara periodik diselenggarakan melalui kegiatan pemantauan rutin, supervisi, pembandingan, rekonsiliasi dan tindakan lain yang terkait dalam pelaksanaan tugas.

2. Pemprov Papua perlu melakukan pembinaan dan pengawasan berkala dengan memberikan bimbingan, supervisi, konsultasi, pendidikan dan pelatihan serta menginformasikan secara berkala kepada aparatur yang terkait dengan pengelolaan keuangan daerah, khususnya kepada bendahara penerimaan dan bendahara pengeluaran sehingga dapat meningkatkan pemahaman terkait prosedur pengelolaan keuangan daerah.

3. Pemberian reward kepada instansi yang mampu mengelola keuangan daerah sesuai dengan Prosedur Operasional Standar yang ditetapkan.

4. Pemberian sanksi kepada instansi yang tidak patuh terhadap POS pengelolaan keuangan daerah sesuai dengan kerugian yang dialami pemerintah Provinsi Papua.

\section{DAFTAR PUSTAKA}

Darise, Nurlan. 2008. Pengelolaan Keuangan pada Satuan Kerja Perangkat Daerah (SKPD). Penerbit PT.Indeks, Jakarta.

Jaya W.K. 1999. Analisis Potensi Keuangan Daerah, Pendekatan Makro. PPPEB UGM Yogyakarta.

Mamesah, D.J. 1995. Sistem Keuangan Daerah. PT.Gramedia Pustaka Utama, Jakarta. 
Mardiasmo. 1999.Otonomi Daerah Berorientasi kepada Kepentingan Publik, National Seminar Promoting Good Governance, Yogyakarta: BPFE UGM.

Peraturan Pemerintah No.79 Tahun 2005 tentang pedoman pembinaan dan pengawasan penyelenggaraan pemerintahan daerah.

Peraturan Pemerintah No.58 tahun 2005 tentang pengelolaan keuangan daerah.

Peraturan Pemerintah No.24 tahun 2005 tentang standar akuntansi pemerintahan.

Permendagri No.13 tahun 2006 tentang pedoman pengelolaan keuangan daerah.

Permendagri No.59 tahun 2007 tentang perubahan atas peraturan menteri dalam negeri No.13 tahun 2006 tentang pedoman pengelolaan keuangan daerah.

Rahman, A. S. 2003. Manual prosedur operasional standar. Perpustakaan Universitas Indonesia Depok.

Tambunan,R.M. 2008. Standard Operating Procedures (SOP). Maiestas Publishing. Jakarta.

Undang-Undang No.1 Tahun 2004 tentang Perbendaharaan Negara.

Undang-Undang No.15 Tahun 2004 tentang pemeriksaan pengelolan dan tanggung jawab keuangan negara.

Undang-Undang No.21 tahun 2001 tentang Otonomi Khusus (Otsus) bagi Provinsi Papua.

Undang-Undang No.32 tahun 2004 pemerintah daerah.

Undang-Undang No.33 tahun 2004 tentang perimbangan keuangan antar pemerintah pusat dan daerah. 